\title{
ESSAY
}

\section{All the President's scholarly men}

\author{
Barack Obama's choice of science advisers is cause for celebration. Yet history shows that an impressive \\ academic record doesn't guarantee good, impartial advice, cautions Robert Dallek.
}

President Barack Obama's appointment of academic scientists and economists to positions of high authority in his administration has created the sort of excitement in universities and among researchers that has not been seen for eight years. Certainly, after George W. Bush's grudging agreement to a constricted programme of stem-cell research and his politicization of scientific findings about the environment, Obama's choice of prominent scholars is a breath of fresh air.

Yet before the country's, or indeed the world's, academics become too excited about the latest professors at the White House, they would do well to recall that US presidents have repeatedly turned to academic stars for advice during the past century, with mixed results. That academics have an imperfect record as presidential advisers is not to doubt that their expertise has considerable value. But no one should assume that an impressive academic track record guarantees good policy. Far more important is an ability to remain independent and offer advice based on sound evidence.

\section{The good and the bad}

Among the most striking achievements by academic insiders in presidential administrations is that of the 'Brain Trust', a group of Columbia University professors who counselled Franklin D. Roosevelt on how to repair the damage caused by the Great Depression ${ }^{1}$. Also high on the list in importance is the work of Robert Oppenheimer, a physicist from the University of California, Berkeley.

In June 1941, almost two years after Albert Einstein had alerted President Roosevelt to the possibility of building an atomic weapon, Roosevelt created an Office of Scientific Research and Development. Oppenheimer became the chairman there of a subcommittee charged with designing the A-bomb. In March 1943, when the US Army selected Los Alamos, New Mexico, as the site where the work would be done, Oppenheimer became the principal architect of the weapon.

Fear that Hitler's Germany would claim victory in the race for the 'winning weapon', as some called it, were overblown, although the limits of Germany's capacity to build a bomb were not fully understood until later. Despite this - and retrospective qualms voiced by Oppenheimer and several of his colleagues about building so destructive a weapon - the
United States' success in designing, testing and using the A-bomb was testimony to an extraordinary cooperation between the federal government and the scientific community ${ }^{2}$.

A comparable success story is Henry Kissinger's role in shaping some of Richard Nixon's foreign policies. Kissinger was a professor of government at Harvard University. As national security adviser and later also secretary of state, Kissinger helped re-establish Sino-US relations in 1972. That meant ending 23 years of animosity over China's turn to Communism and participation in the Korean War, in which US forces had fought to prevent the Communist North Korean state from taking over South Korea.

Kissinger was also an architect of the policy of 'détente' in the cold war with the Soviet Union. Among the measures to 'de-escalate' tensions between the United States and the Soviet Union that he helped put in place was an agreement to limit arms - a dramatic step away from the sort of tensions that had brought the two nations to the brink of nuclear war during the Cuban missile crisis. And by helping to end the Vietnam war, for which he received a Nobel Peace Prize, and paving the way to the Camp David peace accords between Egypt and Israel following war in 1973, Kissinger helped Nixon establish peace in critical conflict zones.

Yet, like two of his immediate academic predecessors as national security adviser, McGeorge Bundy and Walt Rostow, Kissinger also made miscalculations that cost the nation blood, treasure and prestige. At the start of Nixon's term in 1969, Kissinger supported the president's decision to keep troops in Vietnam. Staying in the war brought an additional 23,000 military deaths and failed to save Saigon from a North Vietnamese conquest in 1975. Likewise, Kissinger's collaboration with Nixon in helping the Chilean military topple democratically elected Salvador Allende undermined US standing across Latin America and opened the way to Augusto Pinochet's 17-year dictatorship ${ }^{3}$.

Earlier errors of judgement by Bundy and Rostow should have been cautionary tales for Kissinger. Bundy joined John F. Kennedy's administration as national security adviser in 1961. This was a post Rostow later assumed during Lyndon Johnson's presidency after
Bundy disagreed with the president on how to encourage public backing of the Vietnam war. A professor of government and the youngest dean of faculty in Harvard's history, Bundy was described by Washington Post columnist Joseph Kraft as "unmatched" in his ability "to articulate and execute public purposes" and as perhaps the only member of the postwar generation in government to deserve "the statesman's mantle". Rostow did not lag far behind in reputation. An economist at the Massachusetts Institute of Technology in Cambridge and prolific author of studies that shaped public thinking about economic growth, Rostow, like Bundy, seemed a natural fit for the position of national security adviser.

However, both men badly misread the ability of the United States to control events in Vietnam: they believed that US forces could help the South Vietnamese government defeat Communist Viet Cong insurgents backed by North Vietnam and could assure the rise of a democratic government in Saigon.

Even after the deaths of nearly 60,000 US soldiers and a Vietnam unified under Communist control, Rostow would never concede that sending troops to Vietnam had been a mistake. Instead he argued that the war had given other southeast Asian nations time to develop and avoid Communist takeovers ${ }^{4-6}$. Likewise, Kissinger never acknowledged errors in his and Nixon's dealings with Vietnam and Chile - even though he would be hard pressed to find many defenders among historians who have studied them.

By contrast, Bundy shared former defence secretary Robert McNamara's retrospective conviction about the war that "we were wrong, terribly wrong". Indeed, towards the end of his life Bundy wondered how someone as learned as himself could have been so mistaken ${ }^{7}$.

\section{A look ahead}

Among the leading academic lights Obama has chosen to join his administration is Steven Chu. As well as Obama's energy secretary, Chu is a Nobel-prizewinning physicist and former head of the Department of Energy's Lawrence Berkeley National Laboratory in California. John Holdren, a Harvard professor of environmental science, is Obama's science adviser. Harold Varmus, a 


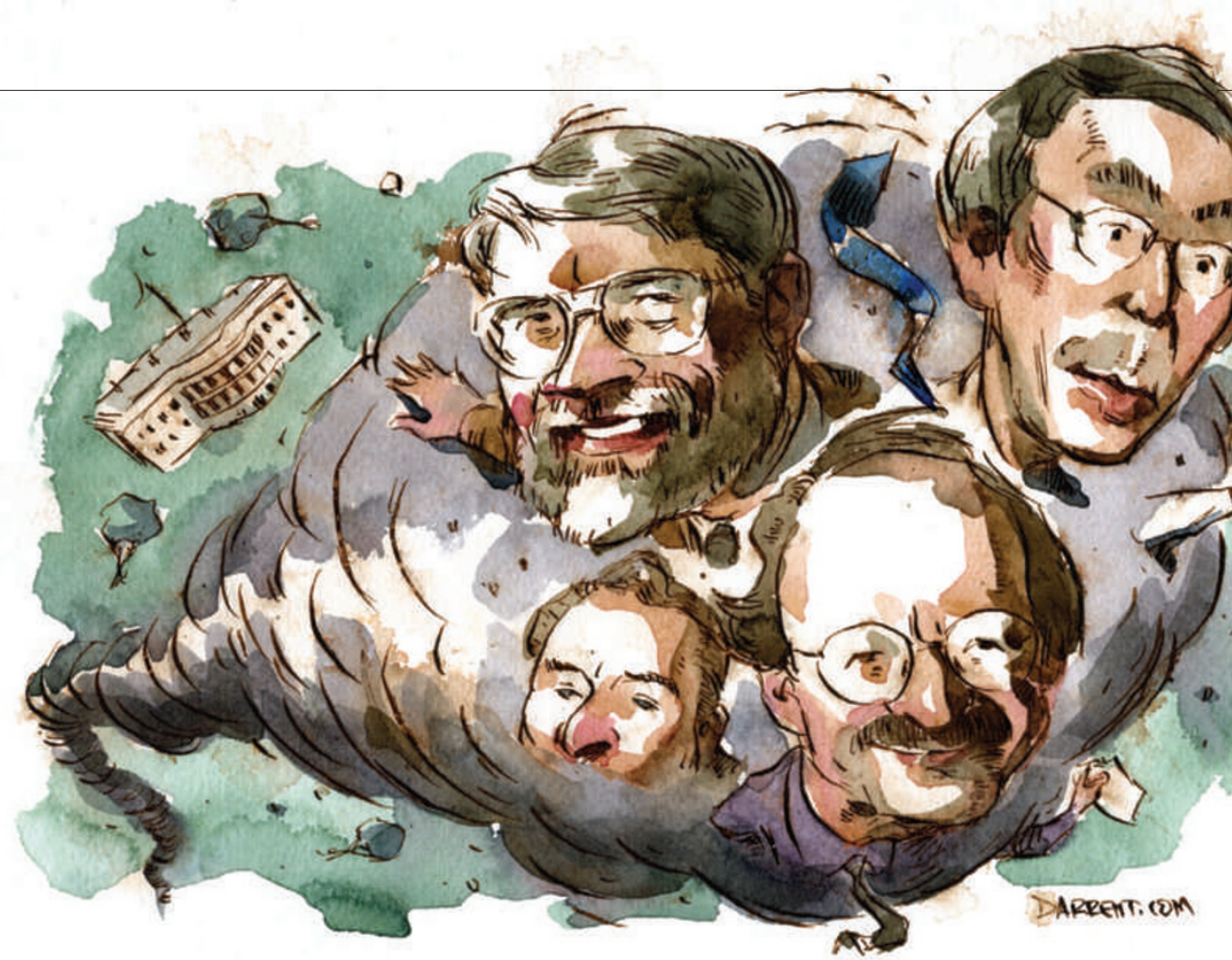

Nobel laureate in medicine, former head of the National Institutes of Health and head of the Memorial Sloan-Kettering Cancer Center in New York, is the chairman of his campaign science advisory council. And Lawrence Summers, the former US Treasury secretary and president of Harvard, heads the White House economic council. What should these advisers, and others besides them, learn from the successes and failures of their predecessors?

The principal lesson I see in assessing the records of intellectually brilliant men such as Oppenheimer, Bundy, Rostow and Kissinger is that academics should always provide advice based on the best available evidence and try not to be swayed by lobbying, or by political or ideological considerations. Total abstinence from politics is not an option, especially for a secretary of energy or a secretary of state who have to take account of both domestic and international political cross-currents, or groups and nations pressing their special interests. Nevertheless, allowing political judgements to overshadow evidence-based understanding is a prescription for making the sorts of errors that are all too common among partisans elected to high offices.

Oppenheimer largely avoided this mistake. He called the bomb "an evil thing" that in time might lead "mankind to curse the names of Los Alamos and Hiroshima". Although he had doubts about building such a destructive weapon, he never allowed his political concerns to interfere with his work.

Bundy and Rostow were different. In heeding political pressures in the White House, they deserted their understanding of how history works. Both advisers believed that a Communist victory in South Vietnam would not only jeopardize Johnson's domestic political standing but also US interests in southeast Asia and Europe, where they feared the Soviets might be emboldened to commit acts of aggression that could threaten a wider war.

The Democratic administration's Bundy and Rostow lived in the shadow of Senator Joseph McCarthy and other right-wing critics, who had pilloried Harry Truman and the Democrats for having 'lost' China to Communism by failing to give sufficient backing to Chiang Kai-shek's nationalist government. Yet their academic expertise should have told them that world events do not simply replicate themselves in vastly different contexts. Vietnam wasn't China. In addition, McCarthyism had lost favour by the 1960s. What's more, there was nothing to suggest that a Communist victory in Vietnam would have any significant effect on the actions of the Soviet Union or China, or on the outcome of the larger cold war.

By focusing so much attention on unrealistic political fears that were largely confined to the White House, Bundy and Rostow encouraged policies that ill-served the United States. They would have served the country better had they devoted more of their efforts to assessing, using the best available knowledge, the likely effectiveness of bombing and ground combat in Vietnam, where the prospects for success were highly questionable.

Kissinger made similar misjudgements. He feared that the collapse of South Vietnam and the continuing control of Chile by a left-wing government would undermine US credibility with both allies and adversaries, and make Nixon vulnerable to charges of having failed to meet the Communist threat in southeast Asia and the western hemisphere. But in 1961, when he became national security adviser, more than three years of US participation in the Vietnam fighting had undermined his country's credibility with both allies and adversaries abroad, not enhanced it. Meanwhile, Fidel Castro's Communist regime in Cuba had turned out to have only limited effect on the United States. This knowledge should have persuaded Kissinger, who prided himself on his standing as a foreign policy realist, to make a quick end to the war and to realize that Allende presented no significant threat to the United States.

Kissinger's deep ties with Nixon almost certainly influenced his thinking. In 1970, Nixon's chief of staff H. R. Haldeman told Kissinger that the president intended to end the US military presence in Vietnam in 1971. Kissinger warned Nixon that if South Vietnam then became unglued, it could jeopardize his re-election in the following year by opening him to attacks for having failed to bring "peace with honour", as he had promised. Instead of making the sort of rigorous calculations about foreign threats a national security official is charged with, Kissinger included domestic political considerations in his advice.

The White House professor may sincerely believe that promoting a president's political standing is vital to the national well-being, but becoming a partisan advocate can be a formula for providing poor advice. In short, professors should confine themselves to what they know and leave the politics to politicians.

Robert Dallek is professor of history emeritus at the University of California, Los Angeles. He is the author of Nixon and Kissinger: Partners in Power (2007) and John F. Kennedy: An Unfinished Life (2003).

e-mail: rdallek@aol.com

\footnotetext{
MacGregor Burns, J. Roosevelt: The Lion and the Fox (Harcourt Brace Jovanovich, 1956).

2. Bird, K. \& Sherwin, M. J. American Prometheus: The Triumph and Tragedy of J. Robert Oppenheimer (Alfred A. Knopf, 2005).

3. Dallek, R. Nixon and Kissinger: Partners in Power (Allen Lane, 2007).

4. Dallek, R. John F. Kennedy: An Unfinished Life, 1917-1963 (Allen Lane, 2003)

5. Dallek, R. Flawed Giant: Lyndon Johnson and His Times, 1961-1973 (Oxford Univ. Press, 1998).

6. Goldstein, G. M. Lessons in Disaster: McGeorge Bundy and the Path to War in Vietnam (Times Books, 2008).

7. McNamara, R. In Retrospect: The Tragedy and Lessons of Vietnam (Times Books, 1995)
} 